\title{
Theorizing the Grounds of Rhetorical Judgment
}

\author{
JOHN LOUIS LUCAITES and CHARLES A. TAYLOR Indiana University
}

Key Words: Prudence; judgment; rhetoric; logic; Persian Gulf War; political debate; decisionmaking.

\begin{abstract}
Prudence has long been an important topic for thetorical theorists and its place in intellectual history is becoming increasingly well documented. This essay develops a conception of prudence as an ideological construct, a term crafted in the history of its public usages to govern the relationship between common sense and political action as enacted in the name of historically situated social actors. From this perspective, prudence represents the recursive interaction between a rhetoric of judgment and the grounds on which that rhetoric is evaluated by a historically particular community of arguers. A case study of the 1991 U.S. Senate debate regarding the authorization of offensive military action in the Persian Gulf illustrates how competing standards of prudential judgment are crafted and evaluated in discursive controversy.
\end{abstract}

When the 102nd Congress met on January 10, 1991 to debate whether or not to grant President Bush the authority to employ American military troops to force Iraqi invaders out of Kuwait, the United States faced its most serious military crisis since the Vietnam War.' The nationally televised debates that unfolded over the next three days in both the House of Representatives and Senate reflected the anxieties of a nation caught between the desire to promote a "New World Order" of peace and freedom, and the fear of becoming the designated enforcer of that order. ${ }^{2}$

Political commentators quickly recognized and valorized the significance of the debates. In one typical journalistic depiction, E. J. Dionne observed "each side was willing to engage the other with civility and a minimum of name calling," indicating that "politicians are still capable of carrying out a serious debate with ... all the gravity the topic of war demands." Professor Kathleen Hall Jamieson was equally enthusiastic in her characterization of the debates as "extraordinary ... ideas were engaging other ideas. We've seen so little of that as a public. ${ }^{\text {"4 }}$ Even commentators adamantly opposed to U. S. Persian Gulf policy, such as Max Elbaum, labelled the debates "tremendously significant and extremely sharp." 5

The clear assumption operating in such reactions is that the Persian Gulf Debates represented American liberal democracy at its best, literally enacting the logic of prudential decision making crafted into the $\mathrm{U}$. $S$. Constitution and its model for a balanced and open government. Of course, such a conclusion represses the fact that before the debates President Bush announced publicly that he was under no legal constraint to seek the advice and consent of Congress to employ the military as he saw fit. Indeed, the President went so far as to suggest that it was only out of common courtesy that he even bothered to request congressional support for his actions in the Gulf, and that in any case he would not be constrained by the outcome of the debates in how he chose to proceed. ${ }^{6}$ He bolstered this position after the fact in March 1991 when he recalled arrogantly that "it was argued that I can't go to war without the Congress. And I was saying I have the authority to do this."

The "civility," "seriousness," and "engagement of ideas" apparent in the debates aside, we have cause to wonder about the rhetorical functions they served. President 
Bush's characterization of the situation might lead one to conclude that the debates were little more than a spectacle, functioning largely to create the illusion of democracy in action. While we certainly do not want to exclude the possibility that the primary function of the debates was consummatory, serving primarily to enhance America's hegemony in the Persian Gulf, we believe that such a conclusion misconstrues and underestimates their rhetorical and ideological significance. ${ }^{8}$ In what follows, we argue that the primary issue at stake in the congressional debates of January 10-12, 1991 concerned less the propriety of America's immediate military action in the Persian Gulf than a more fundamental concern for the rhetorical criteria to guarantee that such action was morally and politically "prudential."

The topic of "prudence" has long been an important consideration for rhetorical theorists, and its place in rhetorical history is increasingly well-documented. ${ }^{9}$ As a classical theoretical construct, "prudence" has existed traditionally in a tension between the Aristotelian notion of phronesis or practical wisdom, defined as an ethical category constituted by the analytical relationship between rhetoric and dialectic, and the more organic, Ciceronian conception of style or decorum, defined as the "propriety" of specific performances of the "art of government."10 In the public practices of Anglo-American liberal democratic government, however, prudence has functioned less as an idealized or reified theoretical construct, than as an ideological token, a word crafted in the history of its public usages to govern the relationship between "common sense" and "political action" as performed or enacted in the name of a historically situated sovereign "people." 11 From this perspective, "prudence" represents the recursive interaction between a rhetoric of judgment and the grounds on which that rhetoric is evaluated by a historically particular community of arguers, its meaning at any given point in time negotiated by competing interests in the crucible of discursive controversy.

When read in the context of a conception of prudence as a rhetorically constituted, ideological commitment of community, the significance of the Persian Gulf debates hinges on their construction of a normative precedent for defining the legitimate or prudent grounds for the use of force as an instrument of American foreign policy..$^{12}$ In particular, we claim that the debates functioned rhetorically to reconfigure the normative logic of congressional decision making, at least in cases where the Constitutional duties of declaring and conducting war are placed in opposition. ${ }^{13}$ Consequently, we hold that the Persian Gulf Crisis was as much-if not more-an ideological crisis of American representative democracy as it was a military crisis in the Middle East.

We develop this argument in two stages. First, we describe the way in which the proponents for the "immediate authorization" of the use of military force followed the lead of President Bush in subordinating alternative viewpoints to the scenic constraints of an arbitrarily constructed, temporal crisis: the United Nations' January 15th deadline for the evacuation of $\mathrm{Ku}$ wait. Second, we examine how the exigence of "time" framed the primary issue of the debates in terms of competing conceptions of prudential decision making. In this context, the supporters of immediate authorization articulated a narrow conception of prudence controlled by material conditions, while the opponents of immediate authorization insisted that Congress remain active agents of judgment, bound only to the necessity of arriving at a pragmatic consensus. ${ }^{14}$

\section{Crafting a Scenic Crisis}

When the Senate convened on January 10th to consider the President's request for congressional authorization to use force in 
the Persian Gulf, it was quickly obvious that the advocates of consent believed that material constraints necessitated immediate congressional action. As Dan Coates (R-IN) volunteered, "it seems to me that this particular situation with the deadline of January 15 approaching, that some type of resolution by the Congress needs to be forthcoming on a relatively quick basis so that we do not send a signal that the Congress does not know where it wants to go. We can put the President and the Secretary of State in an untenable position if debate continued on and on, and particularly approaching that deadline" (S99). ${ }^{15}$ Indeed, the proponents of granting Bush's request were nearly unanimous in their criticism of the Senate itself for delaying the debate until less than a week before the UN deadline. ${ }^{16}$ While it is not at all clear that an earlier debate would have altered its eventual outcome, most Republicans and conservative Democrats contended that, at this late date, prudential judgment entailed subordinating sustained debate and discussion to the myriad material exigencies at hand. ${ }^{17}$

Ironically, the most notable material exigence upon which reasoned judgment was said to rest was the most constructed exigence of all: the January 15 th deadline for Iraqi withdrawal from Kuwait. According to U.N. Res. 678, it was after that date that coalition members could use military action to force Iraqi compliance. Importantly, however, it was not a mandate for the use of force. In technical terms the deadline was a necessary but not sufficient condition for the onset of war. In the Senate debates, however, proponents of the use of force insisted that the deadline rendered all other considerations irrelevant. Recognition of their supposed irrelevance was thus construed as the only prudent course of action. Arlen Specter (R-PA), for example, maintained that "it is too late in the day ... for the Congress meaningfully to disagree with the President's request.... We are much past the point of changing
U. S. or U. N. policy" (S114). William Roth (R-DE) similarly argued that he did "not believe Congress should, at this late date, be trying to pull the rug out from under the President" (S138). As Thad Cochran (R-MS) concluded, "it may be too late ... to make changes now" (S148).

This issue involved much more than a complaint regarding the proximity of the debate to the U. N. deadline. Indeed, the executive request for authorization that motivated the debate was itself made "late in the day," only three days earlier. In a very real sense, the position privileging material exigencies such as time ordained prudential judgment as recognizing the determinism of material conditions and the necessity of subordinating itself to them.

It was precisely in this context that the U.S. Senate became the servant of the narrow material logic it helped to construct. Jesse Helms (R-NC), for example, opined that "for ... months the American people have been subjected to a cacophony of carping criticism and second guessing ... [but] politics must stop at the water's edge. This is no time for posturing politicians to strut across the TV screen, presuming to second guess" (S385). ${ }^{19}$ Helms most clearly subordinated congressional initiative to material conditions when he concluded that "now that the critical moment has arrived, it is time for all of us to stand united behind [Bush]" (S385; emphasis added). Similarly abdicating individual judgment to the compelling march of time was Albert Gore (D-TN), who declared "I cannot reconcile myself to a point of view and a vote that says, in effect, we will let this deadline come and go" (S334). David Durenberger (R-MN) neatly crystallized the available range of rational options when he noted that "We are not permitted the luxury of academic speculation in this debate. Steps have been taken which cannot be taken back. Decisions have been made . . . that cannot be reversed. And whether we like it or not, time is running" (S310). 
We do not mean to suggest that the Senate followed the dictates of U.N. Res. 678 or the Bush administration which spearheaded its passage, in lock-step fashion. Nonetheless, the supporters of the immediate authorization of force depicted the arbitrary deadline of January 15 as the materially over-determined cause for limiting debate and making a quick decision. By doing so, they crafted an ideological standard for Congressional deliberation that insisted on the ineffability of material phenomena and the futility of purposive action in the face of them.

The reification of this rhetorical logic pervaded the debate, structuring the discussion of individual lines of support for the general commitment to authorize force in the Gulf. This emergent prudence, then, functioned recursively both as a potential outcome of the Senate debates, and as the dominant inventional resource within it. ${ }^{20}$

Its inventional authority is neatly illustrated in the controversy surrounding the relative staying power of the international coalition during a sustained period of economic sanctions and military inaction. Praise for the international coalition's unprecedented unity of purpose was frequent and effusive. Warren Rudman (R-NH) noted, for example, that "it is most heartening to observe the international community ... consistently support the coalition opposed to Iraq's aggression. The significance of this unified stance ... cannot be overstated" (\$325)..$^{21}$ In the coalition, it was argued, lay the embryonic "New World Order" so widely heralded by George Bush on the collapse of communism in Eastern Europe. Peering into the future, John McCain (R-AZ) predicted that "this is a critical point in history. We determine whether we . . can act together with the United Nations and every other civilized nation in the world, to prevent naked international aggression of the most heinous and disgraceful kind. ... [I]f we fail to act, our New World order will be inevitably a succession of dictators" (S233). Perhaps seeing the New World already fully formed in the coalition, John Danforth (RMO) described the Persian Gulf crisis as "the first major test of the post cold-war world order" (S122).

Even in the New World Order, of course, prudent action would privilege material constraints on human judgment. Rudman warned that "the current international consensus will not last indefinitely ... particularly among the Arab members of the coalition" (S325). John Breaux (D-LA) concurred, noting "I am also concerned that the coalition facing Iraq will break apart if Congress votes to defer .... Fractures between the United States and the allies are becoming apparent and these schisms are likely to expand in the future" (S235).

What seems especially significant here is that the relative fragility of the coalition was attributed not to the fundamental cultural and strategic differences among the allied nations, but to the chronological inevitability of the coalition's collapse. Material time, it seems, would be even more debilitating to the alliance than the actual onset of hostilities in which a then still unknown number of combatants would certainly die. ${ }^{22}$ William Cohen (R-ME) insisted that failing to authorize an immediate military response to the material timeline in the sand would "let [Saddam Hussein's] soldiers lick the bones of those they butchered... [and] stuff our ears with the cotton wool of rhetoric" (\$333). Consequently, the exercise of prudential judgment was taken to dictate presumptive (pre-emptive?) action, rather than forbearance in the face of scenic exigencies.

The ideological effect of this rhetorical logic was to insure that the decision to wage war could not be made in any meaningful way, for it had been materially ordained. The only question remaining was how quickly Congress would realize it and react accordingly.

We do not mean to suggest here that U.S. military involvement in the Persian 
Gulf was truly overdetermined by material constraints. Indeed, the law required that congressional judgments be made to enable both the initial deployment of troops and their subsequent shift to offensive status, as well as the appropriation of funds to equip, feed, and house them. We do maintain, however, that the language in which those judgments were cast was effectively univocal: the abdication of senatorial responsibility literally and metaphorically installed George Bush as the solitary voice publically articulating American Persian Gulf policy.

Pragmatically speaking, the reason for this was quite simple: the proponents of immediate authorization successfully portrayed the multiple voices characteristic of congressional deliberation as a cacophonous confusion leading inexorably to delay and inaction. Malcolm Wallop (R-WY), for example, seemed resigned to abdicate Congressional authority in deference to the executive's vision and purpose. "Sadly," he noted, "what has taken place today, somehow or another is a means of carrying on a debate ... to avoid being pinned with a decision the likes of which the President... cannot avoid. . . Regrettably, the modern Congress is designed to evade its responsibilities." The Persian Gulf debate, he argued, illuminated "just how prone we are as a body to avoid discussing the demands and the fulfillment of national interests" (S272-273). Helms similarly justified the multivocal Senate's deference to the President's efficient univocality: "We have to face this problem now and the way to face it is to back this President" (S147). Alfonse D'Amato (R-NY) pointedly concluded that "to take the President on the way we have sends a terrible signal. And it is wrong" (S233).

That President Bush spoke as the synechdocal voice of the nation was most graphically illustrated in the Senate's reaction to Iraqi Foreign Minister Tariq Aziz's rejection of Bush's personal letter to Saddam Hussein. Secretary of State James Baker attempted to deliver the letter in Geneva, but Aziz rejected it because he considered its tone too condescending and aggressive for communication between heads of state. ${ }^{24}$ Rather than treating Aziz's behavior as a violation of international decorum, or even as a case of diplomatic one-upsmanship, it was characterized in the debates as a personal insult to Bush and, hence, a provocative affront to America. Cameron Burns (R-MT) insisted that anything that threatens Bush's "standing in the international community" does "the American people, not just President Bush, a great injustice" (S248). This, of course, underscored the material necessity of authorizing Bush to use "all necessary means" to dislodge Iraqi troops from Kuwait and, in so doing, to redeem both his and the nation's wounded pride.

The personal insult to Bush was less significant than its characterization as a necessary and sufficient warrant for accepting the prudence of his individual policy making. The effect of the characterization was to produce what Theodore Draper aptly described as a "peculiarly presidential war." 25 Phil Gramm (R-TX), for example, claimed that "Now, more than ever, we must speak with one clear voice, and ultimately, that is the voice of the President" (S328). Robert Kasten (R-WI) concurred, insisting on the necessity of prudential judgment as rendered through "one voice" (S389).

\section{Contesting Prudence}

While the rhetorical logic of prudence that ultimately triumphed in the debates and underwrote their outcome privileged univocal reactions to material constraints, this rhetorical effect emerged neither in isolation nor without considerable controversy. That the votes rejecting the Mitchell-Nunn Resolution and affirming the Dole-Warner Resolution (46-53 and 52-47, respectively) were so narrowly decided 
indicates the relative strength of opposition to military action in the Gulf and, we think, the contours of a competing standard for communal judgment.

Whereas supporters of offensive military action called the legitimacy of the debates themselves into question by claiming that impinging scenic conditions demanded "action, not talk," supporters of the Mitchell-Nunn Resolution articulated a procedural logic indebted to constitutionally mandated deliberation. Whatever the material conditions might be, it was suggested, the legal demands of Article I, Section 8 of the Constitution and the 1973 War Powers Resolution mandated sustained deliberation. As Mitchell remarked in opening the debate, "[T]oday the Senate undertakes a solemn constitutional responsibility; to decide whether to commit the nation to war. In this debate, we should focus on the fundamental question before us: What is the wisest course of action for our Nation in the Persian Gulf crisis?" (S101) Biden was perhaps even more vivid: "The Constitution-even if we wished not to-demands that we debate the question. We are here today because our Constitution, a document written by men who shed blood to free this land from tyranny of any one individual, commands the Congress to decide the gravest question any country faces: Should it go to war?" (S1 19)

Framed as the enactment of the obligations associated with a procedural logic, this conception of prudence was not reducible to a particular position on the authorization of offensive military action. Rather, it stipulated the grounds on which any position on that issue must ultimately be decided. It did not necessarily entail a vote against authorizing an attack on Iraq; it simply altered the standard to which such a vote must be held accountable.

A prudence requiring decision-makers to engage myriad issues in rendering judgments and to accept responsibility for their results stands in stark contrast to the chilling simplicity of reacting to overdetermined material constraints. Enacting the constitutional requirements of judgment yields rhetorical effects without transparent guarantees of success or readily available scapegoats in the event of failure. Rejecting a standard of prudence predicated on reaction to material conditions in favor of one that assumes the ultimate indeterminacy of those conditions highlights the responsibility lying with the agents of judgment themselves. Carl Levin (D-MI) conceded that "since none of us has a crystal ball, we are left with a calculation when it comes to the option of war. ... And the equation being weighed throughout our society is this: Is the abandonment of sanctions to the option of war worth the price we will surely have to pay?" ( 3302 )

The marginalized effect of this rhetoric was to characterize the material conditions considered so clearly determinative by Bush and his congressional allies as subject to variable interpretation. Hence, such exigencies could be taken to warrant a number of different means to the end of mandating an Iraqi withdrawal from Kuwait. John Kerrey (D-MA), lamenting the narrow range of options afforded by a premature surrender to a material logic, argued that it "is a terrible way to make policy . . . but it is even an even more terrible way to go to war by any account... I would rather vote for good prudent policy which would have the same good end result or which, if it ultimately brings you to war, it does so because there was no other option" (S251). Wyche Fowler (D-GA) maintained that Iraq's material brutality had been hastily translated into a material justification for war, preventing meaningful consideration of other, more peaceful, responses. He argued that "there is a difference between a war being just and a war being prudent ... We should choose the war option only when other, less costly, less risky alternatives such as the use of economic and political sanctions are shown not to be able to achieve our objectives" (S243). 
The potential effect of this "adversative" logic was to alter the fundamental standard by which American Persian Gulf policy options could be evaluated. Whereas the dominant conception of prudence in the debates concerned the (re)action to discrete material situations, the alternative celebrated forbearance in the face of uncertainty. For opponents of immediate authorization, patience was indeed a [prudential] virtue. Biden, for example, questioned the wisdom of using our discomfort at the slow pace of sanctions as justifications for immediate (re)action: "The President says he is angry, he is impatient. Well, God bless him, so are all of us. But is that a reason?" (S335) As he further described it in the closing hours of the debate, "wisdom, I am convinced, lies in the case for a policy of patient strength" (S337). ${ }^{26}$ Terry Sanford (D-NC) observed likewise that "To go to war now is not only unacceptable impatience, but I suggest a lack of real courage . . . Let us stand tall and strong and firm. Let us not take the quick and easy way" (\$277).

Prudence, defined in this way, did not rule out material motivations for action. The illegality of Iraq's invasion of Kuwait and the brutality of its occupation cannot reasonably be denied. However, as articulated by opponents of authorization, prudential judgment would not confuse the is of Iraqi action with the ought of an immediate U.S. military reaction. Rather than being trapped by material exigencies, the oppositional rhetoric of the Mitchell-Nunn Resolution charged the Senate with sustaining the search for alternative methods of altering those exigencies.

The contrast of these competing logics is most graphically illustrated in the controversy surrounding the ultimate locus of responsibility for instigating US military action. Responding to suggestions that Saddam Hussein materially dictated American military policy, Robert Byrd (D-WV) insisted on the independent exercise of congressional judgment: "whether or not we go over the brink next Tuesday after midnight . . . is our decision and not Hussein's" (\$357).

Of course, such a standard of judgment is not without its dangers. The broad, even confusing nature of prudence articulated by opponents of force authorization could easily collapse under the weight of its own indeterminacy. After all, judgments do have to be made, and someone has to make them. For proponents of immediate authorization, vesting President Bush with the univocal authority to speak a policy of reaction was a convenient solution. For opponents, however, the rhetorical obligation was to enact a prudentially consensual judgment. Thus, in order to stave off the debilitating effects of utter inaction, harmony had to be sought amidst the cacophony of voices describing competing interests, perspectives, and possible solutions.

Mitchell-Nunn supporters sought to avoid what they saw as the reductive personalization of the conflict marking the claims in favor of authorizing force. John Kerrey (D-MA), for example, rejected the common argument that Bush's earlier decisions inflexibly limited Congressional options. He queried, "Are we supposed to go to war because once the President has announced something publicly, to reverse or question him is somehow detrimental to the Nation despite the fact that we are a coequal partner in government?" (S251) Byrd warned against granting Bush the voice of American policy and its concomitant personalization of the conflict as Bush vs. Hussein: "We ought not personalize ... the looming conflict. To do so would cloud our judgment at a time in our lives and our careers that demands from us absolute lucidity" (\$358).

The lucidity Byrd thought crucial to prudential judgment in the debates found itself characterized as freedom from the hubris that empowered calls for war on the basis of wounded national pride. The demands placed on the debate by the agency 
of ordinary constitutional processes were said to require a judgment based on longterm national interests. Edward Kennedy (D-MA) observed that "Bush prides himself on his ability in foreign policy. Undoubtedly, he felt embarrassed by Saddam .... But wounded Presidential pride is not a rationale for war" (S370). Referring to Aziz's rejection of Bush's personal letter, Biden pondered "Is that a reason to send my sons to die? Because we are offended? Is that a defining moment in history, to send a generation ... . to war?" (\$335) David Pryor (D-AR) cautioned against letting "some sort of John Wayne syndrome" dictate the Senate's judgment. "Let us remember," he argued, "that this is not the Super Bowl where everyone walks away alive, It is not an Easter egg hunt where the winners walk away without a scratch" (S332).

Rather than conferring absolute decision-making authority on the President, the opponents of authorization articulated a competing rhetorical logic that was sensitive to the demands of the broader public debate. In the wake of America's involvement in Vietnam, they argued that deliberation on compelling national issues demands at least the recognition of broader constituencies. Levin, for example, claimed that "one of the lessons of Vietnam is that we should not wage war without a consensus of our people: "We owe it to our military forces and their loved ones to send them ... to their deaths only if the American people believe the objective is worth the price" (S302). John Glenn (D-OH) captured the need for a broader consensus when he concluded that "the issue is not whether Congress will or should support the President's actions. The issue is whether the President's actions will be supported by the American people. Presidents do not go to war. . . the nation goes to war" (S314).

This change in the rhetorical locus of judgment entailed a quite different policy decision. Frank Lautenberg (D-NJ) maintained that in order to authorize offensive force the public must "believe that the good of the nation warrants the risk to the lives of their children." That test, he said, "has not been met" (S245). Warning against succumbing to the superficial appeal of ubiquitous yellow ribbons, Lloyd Bentsen (D-TX) insisted that "the truth is that the American people are already divided on the wisdom of war in the Gulf. We cannot wish away those divisions or swallow them up in a great gulp of patriotism" (S224).

In an important way, then, opponents of authorizing military force crafted a standard of prudence predicated on the articulation of competing interests, and on public consensus rather than individual initiative. This standard was not simply invoked to challenge the relative wisdom of Bush's decisions as commander in chief. Rather, it was characterized as a concrete manifestation of a commitment to the procedural logic of the constitutional process. Byrd clearly illustrated the ground of his judgment when he observed that "I took an oath, Mr. President, to support and defend, not the President of the United States . . but to defend the Constitution of the United States" (S358). Bob Kerrey (D-NE), went even further, insisting that to do otherwise would "make Congress nothing more than a rubber-stamp and literally render inoperative our coequal decision-making responsibility in a matter of war and peace. . . We are still a nation of laws and not of men; ... we still elect our presidents: We do not crown them" (S251).

\section{Conclusions}

In a trenchant critique of the President's Persian Gulf policy, Julius Jacobson argued that "Bush has arrogated to himself the purely personal power to order the deployment of troops. . . He assumes the right as President, without any Congressional authorization, to make a purely personal declaration of war, exercising his ... military option." 27 Our analysis of the 
Senate debates does not challenge this assertion so much as it indicates the necessity of expanding our understanding of the larger political significance of the rhetorical process in which the debates unfolded. While Bush was certainly arrogant in maintaining a kind of imperial authority to employ the military as he sees fit, to focus solely on his pronouncements in this regard is to divert attention from the fact that Congress acceded that authority to him. We certainly do not want to trivialize the possibility of very real disagreements among reasonable advocates regarding the relative wisdom of American military policy in the Gulf. Indeed, we even concede the pragmatic necessity of employing military force as a last resort in assuring national security. Nonetheless, it seems clear that the Senate's final judgment in the Persian Gulf Debates was affected less by such disagreements or impending necessity, than by a narrowly circumscribed rhetoric of prudence that reduces public moral judgment to a simple, individual, and purely instrumental assessment of "objective" material conditions.

While we hesitate to claim that the Senate Debates of January 10-12, 1991 will dictate the outcome for all future challenges to the "New World Order," we do believe that they establish a standard for prudential judgment with troubling implications for future American foreign policy-making. Ironically, from our perspective, David Durenberger (R-MN) seemed pleased by this prospect when he proclaimed that "this is . . . a formative time, a time in which events become precedents, when actions become norms of behavior. .. . The values we project at this time, as Americans and leaders of the world, are crucial to the future of . . a new world order" (S309). We do not quarrel with the claim that these debates might well affect the future of this so-called new world order; but at the same time, our analysis of the debates as a rhetorical process leads us to call into question the rhetorical vision of prudence that they entail as some kind of absolute standard. As Bill Bradley (D-NJ) put it, "if this first crisis in the post cold war world is to be resolved simply by a blind rush to the use of force, what is so new about the new world order?" (S137)

While we acknowledge the value of quick and concerted action in certain circumstances, we worry about the way in which such a rhetoric of prudence threatens to subvert the established agencies for warranting such action. To do so is to substitute an unreflective ends/means calculus for meaningful deliberation. Theodore Draper described the subversion of Congressional agency as a "constitutional watershed," arguing that it "has set a precedent which will haunt this country far longer than the Gulf War will remain a vivid memory." While we resist the temptation to put too fine an edge on it, we cannot fail to call attention to Bush's apparent willingness to extend this univocal conception of prudence to other rhetorical situations, as his 1992 State of the Union Address makes clear. ${ }^{29}$

Scholars of rhetoric and informal logic would seem to be uniquely prepared to comment on the implications of the various logics which underwrite decision making in public forums. The importance of our vigilance to such logics is heightened when the decisions being made concern matters of war or peace. In his contribution to the First International Symposium on Informal Logic, Michael Scriven aptly pointed out that "if we spent half the time on soft logic analyses of contemporary problems that we do on national history ... we would double the chances of there being a national history this time next century. " 30

While we would alter his claim to call for rhetorical analyses as well, we share the substance of his concern. If our analysis can be sustained, there was much more at stake in the congressional debates on the Persian Gulf War than the decision to take offensive military action against Saddam 
Hussein. Indeed, there was even more at stake than a territorial squabble between the executive and legislative branches of government. When the U.S. Congress abdicated its judgmental autonomy to a univocal material standard of judgment, it not only circumvented its immediate responsibility to promote public discussion and debate, but it also contributed to the structuring of a conception of prudence that might well be a serious step backwards in time to the days of the imperial presidency. And that, we believe, would only function to undermine the radical potential of an enlightened, liberal democracy in which we acknowledge our leaders as the first among equals, but only one voice among many.

\section{Notes}

1 The UN Resolution establishing a deadline for Iraq's unconditional withdrawal from Kuwait appears to have largely originated in Washington. Jacobson, for example, argues that the Bush administration exerted heavy pressure on the non-permanent members of the Security Council to support Resolution 678. He maintains that Secretary of State James Baker informed the Yemeni Ambassador (who cast one of two dissenting votes) that he had made the "most expensive vote" he would ever make, forfeiting some $\$ 70$ million in proffered American aid to the impoverished nation. See J. Jacobson, "Gulf Crisis: Villains and Victims." New Politics, 3, 1991, p. 5. Similar accounts appear in P. Bennis, "False Consensus: George Bush's United Nations." In P. Bennis and M. Moushabeck (Eds.). Beyond the Storm: A Gulf Crisis Reader (NY: Olive Branch Press, 1991) pp. 112-125; T. Draper, "The True History of the Gulf War," The New York Review of Books, January 30.1992, p. 41; and E. Sciolino, The Outlaw State: Saddam Hussein's Quest for Power and the Gulf War (NY: Wiley and Sons, 1991) pp. $221 \mathrm{ff}$.

2 In the Senate, a resolution co-sponsored by George Mitchell (D-ME) and Sam Nunn (D-GA), denying immediate authorization in favor of continuing a policy of strict economic sanctions, was defeated on a vote of 46-53. Shortly thereafter, a resolution co-sponsored by Robert Dole (R-KS) and John Wamer (R-VA), authorizing Bush to order troops into combat, was passed by a vote of 52-47. [Alan Cranston (D-CA), recovering from cancer treatments, was the only Senator not to vote on the resolutions.] In the House, nearly identical resolutions received similar reactions. Our focus in this essay is on the Senate debates; however, it is our perception that the debate in the House did not differ from them in any significant way.
3 E. Dionne, "Foolishness Falls Victim to War Debate as Eloquence Escalates," The New York Times, January 12, 1991, p. A8.

4 In Dionne, "Foolishness Falls Victim," p. A8.

5 M. Elbaum, "The Storm at Home." In P. Bennis and M. Moushabeck (Eds.). Beyond the Storm: A Gulf Crisis Reader (NY: Olive Branch Press, 1991) p. 151.

6 "Transcript of Washington News Conference," The Washington Post, January 10, 1991, p. A27.

7 Weekly Compilation of Presidential Documents, March 8, 1991, p. 284.

8 On the difference between the "instrumental" and "consummatory" functions of political discourse, see B. Gronbeck, "The Functions of Presidential Campaigning," Communication Monographs, 45, 1978, pp. 268-280.

9 See, e.g., Ronald Beiner, Political Judgment (Chicago: University of Chicago Press, 1983); Victoria Kahn, Rhetoric, Prudence, and Skepticism in the Renaissance (Ithaca: Cornell University Press, 1985); Eugene Garver, Machiovelli and the History of Prudence (Madison: University of Wisconsin Press, 1987); and Robert Hariman, "Prudence/ Performance," Rhetoric Society Quarterly 21, 1991, pp. 26-35.

10 R. Hariman, "Decorum, Power, and the Courtly Style," Quarterly Joumal of Speech, 78, 1991, esp. pp. 152-158. See also R. Hariman, "Before Prudence: Strategy and the Rhetorical Tradition," in B. Gronbeck (Ed). Spheres of Argument: Proceedings of the Sixth SCA/AFA Conference on Argument (Annandale: SCA, 1989), pp. 108-116. For Aristotle's discussion of phronesis, see Book VI (1141a-1145a) of the Nichomachean Ethics in R. McKeon (Ed.). 
The Basic Works of Aristotle (New York: Random House, 1941) pp. 1027-1036; for Cicero's development of the relationship between style, decorum, and propriety (to prepon), see $D e$ Oratore 2 vols., trans. E. Sutton, Loeb Classic Library (Cambridge MA: Harvard University Press, 1967) and De Officis/On Duties, trans. H. Edinger (Indianapolis: Bobbs-Merrill, 1974).

11 In the vocabulary of contemporary rhetorical theory such ideological tokens have been referred to as "ideographs," An ideograph is an ordinary and culturally biased phrase or term that represents in condensed form, the normative, collective commitments of an ideological community. See M. McGee, "The Ideograph: A Link Between Rhetoric and Ideology," Quarterly Journal of Speech, 66, 1980, pp. 1-16; and J. Lucaites, "Flexibility and Consistency in Eighteenth Century Anglo-Whiggism: A Case Study of the Rhetorical Dimensions of Legitimacy," (Ph.D. Dissertation, University of Iowa, 1984).

12 In this sense of rhetorically constraining future action, a rough parallel can be drawn between these debates and Edmund Burke's "Speech on Conciliation." See J. Lucaites, "Burke's Speech on Conciliation as Oppositional Discourse." In M. Leff and F. Kauffeld (Eds.). Texts in Contexi: Critical Dialogues on Significant Episodes in American Political Rhetoric (Davis, CA: Hermagoras Press, 1989), pp. 81-90.

13 As approved by the constitutional convention and ratified by the states, the war power provision of the Constitution. Article I Section 8, reads "The Congress shall have power ... to declare war, grant letters of marque and reprisal." Article II, Section 2, on the other hand, reads "The President shall be Commander in Chief of the Army and Navy of the United States." Despite Gibbons' claim that "the exclusive allocation of the war power to the legislature is a distinguishing feature of the U.S. Constitution," the nation's history has been marked by sustained scholarly, judicial, and political controversy regarding the practical enactment of those powers. See W. Gibbons, "Origins of the War Power Provision," In M. Barnhart (Ed.). Congress and the United States Foreign Policy: Controlling the Use of Force in the Nuclear Age (Albany: SUNY Press, 1987), p. 31. For other perspectives, see F. Wormuth and E. Firmage, To Chain the Dog of War: The War Power of Congress in History and Law (Urbana: University of Illinois Press,
1989); E. Keynes, Undeclared War: Twilight Zone of Constitutional Power (University Park: Pennsylvania State University Press, 1984); and C. Lofgren, "War Making and the Constitution," Yale Law Joumal, 81, 1972, esp. pp. 697-699. In the Vietnam era, this controversy was revisited in the 1973 debates over the passage of the War Powers Resolution. See J. Javits, "The Debate over the War Powers Resolution," in Barnhart, ed. pp. 55-58; J. Javits, "War Powers Reconsidered." Foreign Affairs, 64, 1985, pp. 130-142; R. Pious, The American Presidency (NY: Basic Books, 1979); and R. Darling and E. Mense, "Curbing the Dog of War: The War Powers Resolution," Harvard International Law Joumal, 18, 1977. pp. 55-96.

14 This view of competing standards for rhetorical judgment is consistent with Tindale and Groarke's discussion of the "adversative" audience, "that audience which, while generally rational, does not reason like us, but which, we believe, can be brought to do so." See C. Tindale and L. Groarke, "Logic and Rhetoric: Groundwork for a Synthesis." In F. van Eemeren, R. Grootdendorst, J. Blair, and C. Willard (Eds.). Argumentation: Perspectives and Approaches: Proceedings of the Conference on Argumentation 1986. (Dordrecht: Foris Publications 1987), p. 287. In the Senate debates, supporters and opponents of authorizing force articulated and were bound by different conceptions of prudential judgment.

15 All references to the debate are from Congressional Record-Senate, January 10-12, 1991. Page numbers will be cited parenthetically in the text, e.g. ( $\$ 99$ ).

16 Brock Adams (D-WA) decried what he saw as the hypocrisy of condemning the Congressional delay, noting that "we were asked by the administration to delay this debate" so as to avoid sending "mixed signals to Saddam Hussein" (S304).

17 Our conceptions of material and consensual logics correspond to what Kenneth Burke labelled "scene" and "agency," respectively. For his discussion of the materialism of scene, consult A Grammar of Motives (Berkeley: University of California Press, 1962), esp. pp. 127-170 and Language as Symbolic Action: Essays on Life, Literature, and Method (Berkeley: University of California Press, 1966), p. 360. On agency, see A Grammar of Motives, pp. 275-300. 
18 See, "Transcript of Washington News Conference," The Washington Post, January 10, 1991, p. A27.

19 Note that time here is metaphorically granted material status as the "water's edge."

20 In his discussion of recursivity, Anthony Giddens maintains that social systems are reproduced through interdependent structures that function simultaneously to constitute each other. See his Central Problems in Social Theory: Action, Structure and Contradiction in Social Analysis (Berkeley: University of California Press, 1979), esp. 70-85.

21 Of course, the actual equality of economic and military burden-sharing was, and remains a subject of heated debate. Joseph Biden (D-DE) noted that "of course ... [partners] are in favor of it ... [they] will allow the United States of America to right any wrong in the world. But the truth is that not every member of the coalition will use force if it comes to that" (S119). Nonetheless, the uniquely international character of the coalition is beyond doubt.

22 Sam Nunn, a principal sponsor of the defeated Resolution that would have denied authorization, noted this irony in a column in Washington Post. Quoting Adm. William Crowe, Nunn wrote, "I cannot understand why some consider our international alliance strong enough to conduct intense hostilities but too fragile to hold together if we attempt a peaceful solution" ("War Should Be a Last Resort," The Washington Post, January 10, 1991, p. A21).

23. There was a similar air of inevitability to Bush's official authorization of war. Charac terizing the declaration as simply "another step in a long continuum," a senior U.S. official said "there was a certain inevitability to the process by then ... the decision had already been made" (in Sciolino, The Outlaw State, p. 244). Edward Said satirically observed that "from the moment George Bush invented Desert Shield, Desert Storm was all too logical, and Poppy turned himself into Captain Ahab." See E. Said, "Introduction." In P. Bennis and M. Moushabeck (Eds.). Beyond the Storm: A Gulf Crisis Reader (NY: Olive Branch Press, 1991) p. 1.

24 Presented the letter at the outset of his January 9 meeting with Baker, Aziz was reported to have read it and remarked that he could "not receive this letter .... The language in this letter is not compatible with language between heads of state." (in W. Drodziak, "Baker, Aziz
Describe Six Hours of Talking Past Each Other." The Washington Post, January 10, 1991, p. A23.) Bush subsequently characterized the Iraqi action as a "total stiff-arm. . . a total rebuff." ("Transcript of Washington News Conference." The Washington Post, January 10, 1991, p. A27.) Calls for immediate authorization of force gained significant momentum when the rejection was publicized ("T. Kenworthy and J. Yang, "Support of Bush Authority to Act Seen Enhanced by Iraqi Rebuff." The Washington Post, January 10, 1991, pp. A1, A28.

25 T. Draper, "The True History," p. 39.

26 It is interesting to note here that Biden's criticism is directed at the justifications advanced for a quick authorization of war. He argued that "those who assert the urgency of war have failed to muster a cogent case. Their arguments ... reflect flawed assumptions leading to dangerous folly" (\$337). In one sense, it can be argued that proponents of authorization did not construct a case at all, at least in the traditional sense. Their justification was fundamentally an abdication of judgment to material conditions. More importantly, however, we contend that the crucial "assumption" on which the two sides differed was what constituted prudential judgment.

27 J. Jacobson, "Gulf Crisis: Villains and Victims." New Politics, 3, 1991, p. 5.

28 T. Draper, "The True History," p. 45.

29 In the speech, Bush provides disturbing evidence of subverting agency to material exigencies (including a fading campaign): "I myself have sometimes thought that the aging process could be delayed if it had to make its way through Congress. You will deliberate, and you will discuss, and that is fine. But my friends, the people cannot wait. They need help now" ("Text of Bush's Message," The New York Times, January 29, 1991, p. A14).

30 M. Scriven, "The Philosophical and Pragmatic Significance of Informal Logic," In J. Blair and R. Johnson (Eds.), Informal Logic: The First International Symposium (Inverness CA: Edgepress, 1978), p. 154.

JOHN LOUIS LUCAITES and

CHARLES A. TAYLOR

DEPARTMENT OF SPEECH COMMUNICATION

INDIANA UNIVERSITY

809 EAST SEVENTH STREET

BLOOMINGTON, IN 47405 